DOI: $10.14746 /$ por.2018.2.14

\title{
NIEDOKOŃCZONA PARTIA SZACHÓW: DEMISTYFIKACJA FIGURY OFIARY I SUBWERSJA DYSKURSU ODPOWIEDZIALNOŚCI W POWIEŚCI DANAS JE SREDA (DZISIAJ JEST ŚRODA) DAVIDA ALBAHARIEGO
}

\author{
Tatjana Rosić ${ }^{1}$ \\ (Institut za književnost i umetnost)
}

Słowa kluczowe: polityki ojcostwa, syn-narrator, figura ofiary, świadectwo, kultura pamięci, komunizm, subwersja, odpowiedzialność, Socjalistyczna Federacyjna Republika Jugosławii Keywords: policies of fatherhood, son-narrator, the figure of the victim, the witness, the culture of memory, communism, subversion, responsibility, Socialist Federal Republic of Yugoslavia

\begin{abstract}
Abstrakt: Tatjana Rosić, NIEDOKOŃCZONA PARTIA SZACHÓW: DEMISTYFIKACJA FIGURY OFIARY I SUBWERSJA DYSKURSU ODPOWIEDZIALNOŚCI W POWIEŚCI DANAS JE SREDA (DZISIAJ JEST ŚRODA) DAVIDA ALBAHARIEGO. „PORÓWNANIA” 2 (23), 2018. T. XXIII, S. 201-212. ISSN 1733-165X. Powieść Davida Albahariego Danas je sreda (Dzisiaj jest środa) należy do tych powieści (post)jugosłowiańskiej produkcji literackiej, które od 2010 roku poddają krytycznemu oglądowi polityki ojcostwa w kontekście mechanizmów pamiętania i zapominania. W pracy zanalizowano modele narracyjne oraz strategie dezintegrujące dookreślone pozycje tożsamościowe relacji ojciec - syn w procesie zaświadczania o przeszłości (mowa tu o takich wydarzeniach, jak np. rezolucja Biura Informacyjnego, tworzenie obozu na Nagiej Wyspie czy rozpad Socjalistycznej Federacyjnej Republiki Jugosławii). Figura ojca stawia czytelnika w obliczu procesów neoliberalnej globalizacji i repatriarchalizacji z jednej strony, z drugiej zaś - konieczności zweryfikowania przeszłości i tworzenia kultury pamięci na obszarze postjugosłowiańskim. Gruntowna demistyfikacja figury ofiary zarówno historycznej, jak i politycznej prowadzi do subwersji dyskursu odpowiedzialności, który w odniesieniu do krajów byłej Jugosławii w tytułowej powieści Albahariego konstytuuje się jako utopijny projekt kultury.
\end{abstract}

1 E-mail: tatjana.rosic@gmail.com 
Abstract: Tatjana Rosić, UNFINISHED CHESS GAME: DEMISTIFICATION OF THE FIGURE OF THE VICTIM AND SUBVERSION OF THE DISCOURSE OF RESPONSIBILITY IN THE NOVEL TODAY IS WEDNESDAY BY DAVID ALBAHARI. "PORÓWNANIA" 2 (23), 2018. Vol. XXIII, P. 201-212. ISSN 1733-165X. David Albahari's novel Danas je sreda (Today is Wednesday) belongs to a group of novels in post-Yugoslav literary production in which - since 2010 - paternity policies have been intensely explored in the context of mechanisms of remembering/forgetting. The paper reviews the narrative strategies of son-narrator testimony by which the stabile identity positions and policies within the complex father-son opposition are disintegrated and and annulled. This disintegration occurs in the process of testifying about the past historical events such as the Informbiro Resolution, the organization of the concentration camp on the Goli otok and the collapse of the SFRY. The father figure also makes the reader face the processes of neoliberal globalization and repatriarchalization, on the one hand, as well as with the necessity of re-examination of the past and establishment of the culture of memory in post-Yugoslav region, on the other. But the fundamental demystification of the figure of the victim - both historical and political - subverts the discourse of responsibility that is established as an already impossible speech in Albaharis novel, branding the post-Yugoslav project of a culture of memory as utopian.

\section{Czuwanie nad historią}

Do chwytów literackich, które w swojej prozie często wykorzystuje David Albahari, należą niespodziewane zwroty akcji. Dlatego czytelników powieści serbskiego pisarza raczej nie zaskoczy tajemnicze zaginięcie jednego z bohaterów spowodowane odejściem czy śmiercią albo - jak w powieści Danas je sreda (Dzisiaj jest środa) budzące niedowierzanie, niewyjaśnione zniknięcie ojca bohatera. Czy ten cierpiący na chorobę Parkinsona człowiek naprawdę przepadł bez śladu, czy pozostał w szpitalu? Może, gdy uwzględnimy jego podeszły wiek i dolegliwości, po prostu zmarł? Albo starannie ukrywa go syn-narrator? Jeżeli tak jest, to dlaczego to czyni?

„Dzisiaj jest środa. Leżę na łóżku, w ubraniu. Leżę i nasłuchuję. Jeżeli się skoncentruję, słyszę wyraźnie: mój ojciec oddycha, mój ojciec szlocha" (Albahari 153). Cytowany fragment przywołuje na myśl rozpoczynający siódmy rozdział Objaśniania marzeń sennych Sigmunta Freuda słynny „sen o płonącym dziecku”. Czuwający przy ciele swojego zmarłego dziecka ojciec śni, że dotyka ono jego dłoni, mówiąc: "Ojcze, czyż nie widzisz, że płonę?" (Freud 1996: 429). Istnieje wiele wariantów tego snu, tak jak wielu jest jego interpretatorów: począwszy od samego Freuda, przez Jacquesa Lacana aż do Slavoja Žižka. Choć w wersji pierwotnej płeć dziecka nie została wyraźnie określona, jego przeobrażenie w chłopca, które dokonało się $\mathrm{w}$ procesie interpretacji, stanowiło wyraz siły oddziaływania istniejącej w kulturze i cywilizacji Zachodu długiej tradycji składania w ofierze niedorosłego męskiego potomka.

Pomyłka nieświadomego przypisania płci popełniona przez Freuda podczas analizy pierwowzoru snu pozwala obnażyć przemilczaną i wypieraną prawdę 
o tym, że rywalizacja ojca z synem, czy też figury ojca i figury syna, bardzo często kończy się złożeniem ofiary z tego ostatniego (np. mit o Edypie rozpoczyna wydany przez Lajosa rozkaz zabicia jego nowonarodzonego syna). Wiedząc o tym, ani Lacan, ani Žižek nie podjęli wysiłku, aby skorygować Freudowską interpretację „snu o płonącym dziecku". Opowieść o tym sennym koszmarze (i o historii ofiarowania) jest jednocześnie opowieścią o upiornym, nieobecnym ciele ojcostwa, nigdy realnym, zawsze jedynie symbolicznym. Jak wskazuje David Lee Miller, ustanawianie symbolicznego ojcostwa jest jednocześnie ujawnianiem jego deficytu w świecie realnym, jego braku i niedoboru, jego utraty: ciało ojca zostaje ukonstytuowane na zasadzie antycypacji w opowieści o nim poprzez interpretację snu o złożeniu ofiary z syna, poprzez nocną zmorę historycznej dekonstrukcji, która, jak się wydaje, wciąż się śni (Miller 176-194).

W powieści Danas je sreda (Dziś jest środa, 2017) Albahariego, podobnie jak we śnie zinterpretowanym przez Freuda w Objaśnianiu marzeń sennych, nocna zmora nie odchodzi, a przebudzenie jest niemożliwe. Różnica polega jedynie na zamianie ról - osobą czuwającą nie jest ojciec, lecz syn, pierwszoosobowy narrator powieści, który, dzięki rozmowom z chorym rodzicem, próbuje zrekonstruować życie swojej rodziny w Socjalistycznej Federacyjnej Republice Jugosławii². Ta męcząca i nadaremna, w dużej mierze nieudana próba rekonstrukcji kończy się niespodziewanym i tajemniczym zniknięciem ojca. Przy jego ciele, hipotetycznie martwym, z całą zaś pewnością nieobecnym, czuwa syn świadomy konieczności zrozumienia prowadzonej przez ojca gry, w której rodzina była jedynie środkiem politycznego ocalenia. Opowieść syna rozpoczyna się sceną podobną do tej, która zamyka jego spowiedź: „Dzisiaj jest środa, dwunasty czerwca, siódma rano. Leżę całkowicie ubrany w łóżku i wsłuchuję się w dźwięki dobiegające z sąsiedniego pokoju. Tam jest mój ojciec" (Albahari 5).

Niezwykła sytuacja, w której narrator leży kompletnie ubrany w łóżku, przywołuje zwyczaj wystawiania ubranego ciała zmarłego na widok publiczny. Otwierająca i zamykająca powieść rytualna scena czuwania symbolicznie wyznacza ramy opowieści narratora-syna o opiece nad starym, cierpiącym na chorobę Parkinsona ojcem. Izolacja wymuszona przez postępującą demencję, na którą cierpi (lub którą symuluje), umożliwia mu uniknięcie odpowiedzialności za czyny związane z jego niegdysiejszą działalnością polityczną.

Skomplikowane i dynamiczne relacje ojca i syna stanowią dla autora powieści impuls do postawienia szeregu pytań związanych ze statusem i tożsamością bohaterów. Dotyczą one tego, kto jest w tej opowieści świadkiem, a kto tym, który poświadcza świadectwo. Kto jest prześladowanym, a kto prześladowcą? Najbardziej istotny wydaje się jednak problem, kto w opowieści o nieudanych próbach rekonstrukcji rodzinnej historii i politycznej przeszłości SFRJ jest naprawdę żywy, kto zaś

2 W dalszej części tekstu zamiast pełnej nazwy używany będzie skrót SFRJ - przyp. red. 
jest martwy. Kto jest prawdziwą ofiarą? Te pytania nasuwa zamykająca powieść wypowiedź narratora, który zwraca się do swojej siostry słowami:

\begin{abstract}
"Umarliśmy", [...] a mieliśmy żyć! Pozwoliliśmy ojcu, aby z nas uczynił posłusznych wykonawców swojej woli, myśląc przy tym, że działamy wbrew niej. „Ojciec”, wykrzyknąłem, „ach, ojciec, ten pocieszny krętacz, odegrał przed nami rolę swego życia, a teraz cieszy się nowo zdobytym statusem cierpiącego na demencję; statusem umożliwiającym mu wybór rozmówcy i sprawiającym, że nigdy nie zostanie uznany winnym tego, co uczynił lub powiedział" (Albahari 151).
\end{abstract}

Ze względu na fakt, że w powieści Albahariego nie pojawiają się żadne zwłoki, należałoby także zapytać, do kogo należy nieobecne ciało, przy którym odbywa się czuwanie? Czy należy ono do ojca, zaś czuwający przy nim syn, śniąc o obecności zmarłego rodzica, podejmuje daremny wysiłek rekonstrukcji wiecznie martwego ojcostwa czy też jego wiecznie martwego upiora? Czy jest to ciało historii uśmierconej wraz z ojcem, który w trakcie całej opowieści nie udzielił odpowiedzi na pytania swojego dorosłego dziecka? A może ciało, przy którym odbywa się czuwanie, należy do syna, milczącego $\mathrm{w}$ obliczu nieprzeniknioności historii i nieodpowiedzialności rodzica mierzącego się z niezrozumiałym dla niego i nienazwanym prawdziwym imieniem widmem przeszłości, z faktem, że był jedynie marionetką w rękach człowieka, który miał go ochronić przed nadciągającą burzą historii? Czy jest to może ciało SFRJ, której opresyjną rzeczywistość ojciec wprawnie zbywa milczeniem, udzielając niepełnych odpowiedzi i odmawiając ułożenia z rozproszonych fragmentów opowieści - tak potrzebnej synowi - historycznej układanki?

W twórczości Albahariego Danas je sreda jest pierwszym utworem podejmującym otwarcie krytykę SFRJ jako autorytarnego i opresyjnego systemu, w którym podkomendni odznaczają się samowolą i bezdusznością, cechującą również ich partyjnych przywódców.

\title{
Partia szachów, ryzyko i problem odpowiedzialności
}

Powieść serbskiego pisarza jest próbą rekonstrukcji przemilczanej historii rodzinnej i upadku SFRJ. Choć przeszłość przeplata się w utworze z losami świadków historii, to jednak Albahari rozpatruje kwestię odpowiedzialności nie w szerokiej perspektywie społeczno-narodowej, lecz na planie jednostkowym. Ikoniczne imaginarium socjalistycznej jugosłowiańskiej rodziny zostaje w książce zrekonstruowane jako puzzle przedstawiające ideologiczne aspekty roli odegranej przez ojca w mrocznej historii rodzinnej oraz funkcje ojcostwa w życiu konkretnych wspólnot narodowych i kulturowych. 
Powieść Albahariego stanowi egzemplifikację dyskursywno-narracyjnej „wojny" prowadzonej w krajach byłej Jugosławii w celu zdobycia prawa pierwszeństwa do interpretacji wydarzeń związanych z rozpadem SFRJ. Potrzeba rekonstrukcji mitologii utraconego świata świadczy o tym, że przeszłość nadal jest dłużniczką teraźniejszości. Pomimo faktu, że poczucia krzywdy doznanej ze strony ojca, rodziny i systemu politycznego nie podziela nikt inny, nawet siostra narratora, jego opowieść staje się świadectwem potencjalnej ofiary.

Męski głos literatury XX wieku był, jak twierdzi Silke-Maria Weineck na początku pracy The Tragedy of Fatherhood (Tragedia ojcostwa), , [...] głosem syna, który rozmawia z ojcem i mówi o nim tonem gniewu i żalu, buntu i tęsknoty, pogardy, potępienia, poczucia winy, strachu i tylko sporadycznie miłości" (Weineck 1). Zdaniem cytowanej autorki, interpretatorki klasycznych utworów zachodniego kanonu literackiego i obecnej w nich figury ojca, $\mathrm{z}$ racji swojej uprzywilejowanej pozycji literatura posiada zdolność odtwarzania dogłębnej relacji między „ideą ojcostwa i ideą politycznej mocy [...], relacji, zależnej od niebezpiecznej logiki metafory, która oscyluje od tezy o zamienności obu tych idei do twierdzenia wręcz przeciwnego" (Weineck 14). W społecznym procesie sprawowania władzy istnieje, twierdzi badaczka, wzmożone zainteresowanie relacją ojciec - syn spowodowane sekwencyjnością przekazywania władzy: prawo albo nakaz dziedziczenia po mieczu stawia syna w sytuacji konieczności szacowania kosztów każdej, a więc i własnej potencjalnej mocy politycznej poprzez jej odrzucanie albo pogardzanie nią w odwiecznym dialogu z najczęściej nieobecnym, utraconym lub martwym ojcem, którego symboliczną władzę, o czym pisał już Freud w studium Totem i tabu, umacnia jego śmierć (Freud 1993: 141).

Syn jest tym, który sam stanie się ojcem i przejmie po nim władzę w ramach wspólnoty nie tylko społecznej, ale także rodzinnej, a zatem weźmie na siebie rolę rodzica, by uczestniczyć $\mathrm{w}$ realizacji dwojakich polityk ojcostwa. W postjugosłowiańskiej produkcji literackiej XXI wieku syn wciąż ma poczucie, że jego zadaniem jest przejęcie roli w spektaklu sprawowania władzy (zanim to jednak uczyni, podobnie jak bohater powieści Danas je sreda domaga się od swojego już nieobecnego, chorego na demencję ojca jakiegokolwiek wyjaśnienia albo wskazówek). Figura ojca jest $\mathrm{w}$ tych powieściach ukonstytuowana jako figura odpowiedzialności, figura, której zadaniem jest wypełnienie jej podstawowej funkcji rodzicielskiej - funkcji obronnej oraz inicjacyjnej, polegającej na wprowadzeniu syna w świat "dorosłych" mężczyzn oraz politycznych rozgrywek na Bałkanach, gdzie zasady gry podlegają ciągłym zmianom.

Narrator powieści Danas je sreda, mieszkaniec wciąż tego samego miasta, ale już innego państwa, staje w obliczu utraty kraju swojego urodzenia oraz końca oficjalnej mitologii rodzinnej, do którego doprowadziła decyzja o sprawowaniu opieki nad ojcem. W kulturze regionu, zdominowanej tradycyjnie przez mężczyzn, autorami opowieści o minionych wydarzeniach są przede wszystkim ojcowie. Tak jest 
również we wspomnianym utworze, nietraktującym - jak słusznie zauważa Teofil Pančić - o chorobie, lecz o figurze Ojca,

[...] autorytarnego, patriarchalnego, tyrana rodziny, który przeobraził się w zawziętego, ale nieporadnego $[\ldots]$ staruszka. Czy w tę niemoc ciała nie jest wpisany los człowieka? Owszem, ale zarówno ojciec, jak i syn oraz wszyscy zainteresowani wiedzą, że to nie wszystko. Czy cielesna choroba jest karą za niegodziwości, których dopuścił się podczas życia? Przecież ojciec wiele i wielu [ludzi - przyp. tłumacza] ma na sumieniu: jako powojenny "esbek” unieszczęśliwił licznych „wrogów ludu”, dopóki sam, jako „informbiurowiec" nie stał się jednym z nich, zakończywszy karierę na Nagiej Wyspie, dzięki czyjemuś raportowi... bardzo podobnemu do tych, które otrzymywał i które wykorzystywał w swojej pracy. Matka narratora zmarła po ciężkiej chorobie dużo wcześniej; matka, którą ojciec poznał jako czupurne dziewczę; matka, która jeszcze od czasów dzieciństwa istniała $\mathrm{w}$ świadomości syna jako kozioł ofiarny ojcowskiej bezwględności, oziębłości, bezgranicznego sadyzmu nieznanego pochodzenia. Tyle że również ta opowieść, jak twierdził ojciec - a nie zapominajmy o tym, że po części ze względu na chorobę, po części z powodu swojego nieczystego sumienia nie jest on „wiarygodnym narratorem" - ma swoje drugie dno, które w tym miejscu niestosownie byłoby odsłaniać (Pančić, źródło internetowe).

Ów „niewiarygodny narrator" u schyłku życia brutalnie konfrontuje syna z „oficjalną wersją" rodzinnej historii, przedstawiając się w niej jako człowiek, który za swoje przekonania płaci kilkuletnim pobytem w obozie na Nagiej Wyspie - miejscu izolacji politycznych wrogów Josipa Broza Tity. Okazuje się jednak, że ojciec nie był wyłącznie niewinną ofiarą systemu komunistycznego, lecz także jego oddanym współtwórcą, który jako cieszący się złą sławą komisarz ferował wyroki śmierci do momentu, kiedy sam stał się ofiarą politycznych rozgrywek po rezolucji Biura Informacyjnego w 1948 roku.

W ostatnich dniach życia ojciec opowiada nie o swojej porażce politycznej zwieńczonej pobytem na Nagiej Wyspie, lecz o okresie politycznej mocy, o strategii rządzenia i kierowania ludźmi, którą jako bardzo młody człowiek świadomie zaadaptował, licząc na to, że przyda mu się ona w niespokojnych czasach:

[...] Słowa goniły słowa, opowieść chciała żyć. W piętnastym lub szesnastym roku życia jako „uświadomiony politycznie” dołączył do młodych komunistów. Dwa lata później został przewodniczącym miejscowego komitetu do spraw odpowiedzialności cywilnej i społecznej, stając się jednym z najbardziej wpływowych ludzi nowej władzy. Zawdzięczał to Dušanowi Ivkovowi, sąsiadowi, który w wolnym czasie grywał z nim w szachy. Ivkov nauczył go ryzyka i patrzenia na świat jak na partię szachów, w której każdy jest pionkiem określonego koloru. „Spójrz”, mówił Ivkov, „czasy królów i królowych się skończyły, teraz zwycięża proletariat, proletariat wspierany przez lekką kawalerię 
i artylerię ciężką. Musisz się nauczyć, podkreślał Ivkov, jak podejmować ryzyko i zwodzić przeciwnika, to wszystko. Gdy go przekonasz, że atak nastąpi z którejś ze stron, a on rzuci na tę pozycję wszystkie swoje siły, wykonasz woltę i uderzysz nieoczekiwanie z innego miejsca. Lekceważ całkowicie straty, świadomie poświęcając pionki, oprócz jednego, który stanie się nową, restytuowaną królową. Będzie ona królową ducha i wolności, a nie, jak ta poprzednia, symbolem arystokracji i anachronizmu" (Albahari 67-68).

Przekazując wiedzę na temat strategii, zdobytą podczas trudnej gry w szachy, ojciec wydaje się szczególnie zadowolony. Udzielona synowi lekcja na temat rozgrywek politycznych jest surowa i niemoralna. Wymaga ona od niego gotowości zmierzenia się z dotąd nieznaną, przemilczaną prawdą o historii rodziny i działalności politycznej ojca. W tej jedynej życiowej lekcji, jakiej pragnie on udzielić swojemu potomkowi, rodzic nie mówi nic o swoich politycznych przekonaniach i ideałach. Ten i taki właśnie syn nie jest przygotowany na akceptację polityki pragmatyzmu, czarno-białego schematu, zgodnie z którym poświęca się zawsze słabszego, choć niekiedy symbolicznie, jak w przypadku „ludu pracującego” SFRJ, wynosi się go do rangi władcy. Powieściowy syn odrzuca możliwość rozegrania z ojcem partii szachów, nie chcąc - jak się wydaje - brać na siebie ryzyka odpowiedzialności poświadczania, stanowiącego warunek odrodzenia lub przynajmniej możliwości dalszego życia:

Dawanie świadectwa jest zatem procesem, w którym narrator (ocalony) odzyskuje swoją pozycję jako świadek: rekonstruuje wewnętrzne "ty”, a przez to potencjalnego świadka lub słuchacza w swoim wnętrzu. [...] Ponowne opisywanie historii życia poprzez dawanie świadectwa jest samo w sobie formą działania, zmiany, która musi się dokonać, by po uwolnieniu było możliwe podtrzymanie życia i jego dalsze trwanie. Zdarzenie musi zostać odzyskane, ponieważ nawet jeśli ulega całkowitemu wyparciu, odgrywa decydującą rolę w kształtowaniu tego, kim jesteśmy i jak żyjemy (Laub 85-86).

Narrator powieści Danas je sreda musi zatem zdecydować, czy może do końca poświadczyć opowieść ojca, godząc się tym samym na przyjęcie lekcji o społeczno-historycznym pragmatyzmie i przetrwaniu jako kategoriach nieuznających imperatywów moralnych.

W czasach upadku reżimu socjalistycznego i porażki komunistycznej utopii, doświadczenia ludobójstwa, bratobójczych wojen, repatriarchalizacji, transformacji ustrojowej i neoliberalnego feudalizmu pozycja ojca staje się ponownie pozycją autorytetu nieobecności. Chociaż pokonany, nadal uparcie odmawia on synowi pomocy albo też nie jest mu jej w stanie udzielić. Z tego powodu autorytarna figura ojca jest dla syna mroczną traumą, symbolem jej niewyrażalności i nierozstrzygalności. Jej ciszy.

Tylko decyzja o uznaniu danego przez rodzica świadectwa może ojca ponownie uczynić ojcem, podobnie jak w przypadku Ivkova, postaci, która w powieści Alba- 
hariego jest jedną z symbolicznych figur ojcostwa kluczowych dla istnienia patriarchalno-maskulinistycznego paradygmatu władzy na Bałkanach i w niegdysiejszej SFRJ. Synem targają rozterki poświadczające niespodziewane przeobrażenie ofiary w kata: przyjąć czy odrzucić przestrogi ojca? Albo: które przyjąć, a które odrzucić? Zrozumieć czy osądzać? Albo: jak zrozumieć, nie stając się współuczestnikiem? W obliczu tych pytań potomek pozostaje bez odpowiedzi.

Rozwiązanie rodzinnych dylematów przyniosłoby symboliczne katharsis zdezorientowanym synom SFRJ. Jednak w powieści Danas je sreda, podobnie jak w większości współczesnych utworów poświęconych rozpadowi Jugosławii, figura ojca jest figurą milczenia i systemowego zapomnienia. Nie udziela ona żadnych innych lekcji poza tą o pragmatycznych zdolnościach przetrwania, która jest dla syna nie do przyjęcia. Jemu zaś, rozgoryczonemu i zawiedzionemu, demencja jawi się jako strategia autorytarnego przemilczania zbrodni popełnionych w przeszłości:

Sądząc z tego, co pan mówi, pański ojciec świadomie wybrał demencję i zachorował na nią. Nie przypominam sobie, żebym słyszał o czymś podobnym.

"Ja również, ale fakt, że o czymś nie słyszeliśmy, nie oznacza, że taki rozwój wypadków nie jest możliwy, prawda?" (Albahari 151).

\section{Demistyfikacja figury ofiary i subwersja dyskursu odpowiedzialności}

Jeżeli więc naprawdę chciałby dotrzeć do prawdy o historii swojej rodziny, syn powinien dokończyć partię szachów rozpoczętą z ojcem, zaangażować się, podjąć ryzyko odpowiedzialności i przyswoić sobie przynajmniej część ojcowskiej wiedzy na temat pragmatyzmu. Mógłby on pokonać ojca tajną bronią, która pozwoliłaby zakwestionować amoralny życiowy pragmatyzm. Jednak do tego w powieści nie dochodzi: na samym jej końcu syn, z powodu tajemniczego zniknięcia ojca, pozostaje bez szans na spuentowanie swojej opowieści i na to, aby w końcu usiąść przy stole szachowym, któremu od dłuższego czasu się przygląda. Powieść Danas je sreda jest bowiem historią nie o ponownym stawaniu się synem-ojcem, lecz opowieścią o ofiarowaniu i znikaniu. Precyzyjniej mówiąc, o pozbawionej skrupułów stopniowej dezintegracji syna i ojca, o ich zaniku, procesie, w którym udaje się ocalić jedynie dziwną, upiorną więź pomiędzy dwiema opuszczonymi politykami tożsamości, czyli pustymi oznaczającymi. W procesie dezintegracji, a dokładniej wzajemnego (samo)eliminowania i wymazywania precyzyjnie określonych mocnych pozycji tożsamościowych ojca i syna, dzięki parodii i ufantastycznieniu, które Albahari aktywuje dopiero na samym końcu utworu, społeczny status figury ofiary ulega degradacji.

W wielu powieściach serbskiego pisarza pojawia się scena rozstania bohaterów na progu domu - Cink (Cynk), Snežni čovek (Yeti), Pijavice (Pijawki), Brat (Brat) to 
tylko wybrane przykłady. Zakończenie powieści Danas je sreda jest takim właśnie progiem, do którego czytelnik dociera, by ostatecznie zdecydować się na wejście do opowieści lub jej opuszczenie, przyjęcie bądź odrzucenie jej zasad. Czy podobnie jak na początku lektury, gdy zgodnie $\mathrm{z}$ teorią dobrowolnego odraczania niedowierzania Samuela Taylora Coleridge'a zostaje zawarty pakt między pisarzem i jego czytelnikiem, temu ostatniemu uda się przezwyciężyć wątpliwości i przyswoić sobie opowieść, tym razem retrospektywnie?

Ambiwalencja zakończenia jest nie tylko niewinną grą fikcji i fakcji, autobiografii i wyobraźni, wizji pisarza i czytelniczej interakcji z "dziełem otwartym”, lecz także probierzem siły opowieści i jej magii, wyzwaniem rzuconym czytelnikowi w momencie, w którym sądzi on, że większość już zrozumiał i przyswoił, a narrator nie jest już w stanie niczego mu zaoferować, ponieważ opowieść osiągnęła cel, do którego zmierzała, a więc swój koniec (Brooks 90-112).

Odraczanie końca i odnawianie paktu z czytelnikiem w powieściach Albahariego stanowi nieuniknioną i konstytutywną część jego narracyjnej strategii. Zabieg ten ma na celu wyeksponowanie fantastyczności i parodyjności, które dzięki otwartemu, zaskakującemu, paradoksalnemu zakończeniu stanowią impuls do zweryfikowania oczywistej na pierwszy rzut oka struktury narracyjnej przeczytanej powieści.

W tragikomicznym zakończeniu powieści ojciec zostaje zdemaskowany nie jako ofiara rezolucji Biura Informacyjnego, ale jako ofiara własnego pragmatyzmu i zapobiegliwości, potrzeby uczestniczenia $\mathrm{w}$ prowadzących do śmierci ryzykownych układach sił. Figura ojca ulega zatem korozji, przemianie w figurę starca - ofiarę upływającego czasu i śmiertelności. Kiedy ojciec uporczywie domaga się, by mu kupić viagrę, syn, który wykazuje wiele współczucia dla starzenia i ułomności fizycznej rodzica, przypominając sobie jego witalizm, pragmatyzm i ostrożność polityczną, stwierdza:

Czasem czuję, że grzeszę wobec ojca. Próbuję go sobie wyobrazić jako ofiarę, ofiarę systemu, okoliczności, błędnych przekonań, ale wówczas przypominam sobie wszystkie te rzeczywiste ofiary, które pozostawił po sobie, i wiem, natychmiast wiem, że on, mimo wszystko, nie zasługuje na wybaczenie. Człowiek musi być odpowiedzialny za swoje życiowe wybory, święcie $w$ to wierzę, a wszystko pozostałe jest próbą ogrania systemu i porządku, których mariaż tworzy strukturę życia, sieć przez którą przeniknie pająk, ale mucha już nie, mucha w żadnym razie nie (Albahari 148).

Powieść Danas je sreda mówi nie o problemie dawania świadectwa przez ofiarę chorą na demencję, lecz o dawaniu świadectwa przez ofiarę, która nią nie jest. Dokładniej rzecz ujmując, powieść stawia pytanie o to, czy i z jaką dokładnością możemy stwierdzić, że ktoś jest naprawdę ofiarą polityczną? Syn-narrator, który „święcie wierzy", że człowiek powinien odpowiadać za swoje życiowe wybory, sprytnie unika ryzyka odpowiedzialności. Niepewność i targające nim rozterki sprawiają, że 
każda podjęta przez niego decyzja jest zła, przez co oddaje pole silniejszemu, który przybiera postać metaforycznego pająka owijającego siecią zła zwykłych, słabych ludzi. Z tego powodu syn-narrator nie jest figura przypadkowej ofiary, lecz jej cieniem: jak to często ma miejsce w prozie Albahariego im bliżej jesteśmy końca, tym większej korozji ulega pozornie mimetyczna tekstura powieści, spod której wyłania się dziwny świat nieistnienia, świat, w którym zostają zniesione wszystkie pozycje tożsamościowe, świat, który się kruszy i rozpada, unicestwiając nadzieję na możliwość rozpoznania ofiar historii, zrealizowania idei sprawiedliwości społecznej czy rozróżnienia dobra od zła.

Dyskurs fantastyczny w końcowej scenie powieści konstytuuje figurę ofiary jako zjawy lub upiora: ciało znika, podczas gdy do czytelnika dochodzą jedynie niewyraźne dźwięki i westchnienia. Trudno powiedzieć, co wyrażają. Ból? A może strach? Gotyckie podłoże sceny finałowej wskazuje na niemożność uchwycenia tożsamości ofiary i na jej labilność: zarówno ojciec, jak i syn nie mogą stać się wiarygodnymi świadkami przeszłości. Czy decyzję podejmowali zbyt długo? Może niepotrzebnie ją opóźniali i odraczali? Właściwy moment minął i nikt już teraz nie rozumie kakofonicznych dźwięków rwącego się wyznania³

\section{Wnioski albo szach-mat}

Historia relacji ojca i syna rozwinięta przez Albahariego w powieści Danas je sreda jest jedną z wielu opowieści powracających w dziełach literatury światowej i literatur jugosłowiańskich. Jest to powtarzająca się narracja o wspólnocie społecznej: metafora ojcostwa jest zawsze metaforą władzy i mocy politycznej, udanej bądź nie praktyki rządzenia. Jest to także opowieść o ofiarowaniu syna: wszechobecny głos syna-narratora w powieści Danas je sreda odsłania patriarchalną i autorytarną matrycę totalitarnych reżimów XX wieku oraz figurę biologicznych i symbolicznych ojców, którzy ją w procesie konstytuowania męskich modeli władzy na Bałkanach reprodukują, poświęcając najbliższych: rodzinę i syna (Rosić 9-51).

Powieść Albahariego Danas je sreda jest jedną z tych powieści postjugosłowiańskiej produkcji literackiej, które od 2010 roku poddają krytycznemu oglądowi polityki ojcostwa w kontekście mechanizmów pamiętania i zapominania. Wśród nich znalazły się: Ultramarin (Ultramaryna, 2010) serbskiego pisarza Milety Prodanovicia, Otac (Ojciec, 2010) chorwackiego pisarza Miljenka Jergovicia, Jugoslavija, moja dežela (2012, Jugosławia, mój kraj) słoweńskiego pisarza Gorana Vojinovicia, Moj sin Hakleberi Fin (2016, Mój syn, Huckleberry Finn) Bekima Sejranovicia, w których, po-

3 Problem odpowiedzialności w powieści Albahariego Brat omówił Nikola Đoković, który zwraca uwagę na fakt, że kakofonia umożliwia zarówno zdemaskowanie ofiary, jak i demistyfikację samej kwestii historycznej i politycznej odpowiedzialności (Đoković 152-154). 
dobnie jak w omawianej powieści, figura ojca i sposób rozumienia polityki ojcostwa jest kluczem do zrozumienia społecznych i politycznych uwarunkowań regionu. $\mathrm{W}$ powieściach tych figura ojca konfrontuje nas z procesami neoliberalnej globalizacji i repatriarchalizacji z jednej strony oraz z koniecznością zmierzenia się z zapomnieniem i postulatem budowania kultury pamięci poprzez ujawnianie społeczno-psychologicznych powiązań pomiędzy, na pierwszy rzut oka przeciwstawnymi, paradygmatami ideologicznymi - z drugiej.

Zezwierzęcenie społecznej funkcji ojcostwa, aby posłużyć się określeniem Milety Prodanovicia z powieści Ultramarin (Prodanović 96), jest procesem przebiegającym równolegle ze zjawiskiem utraty polityczności. W sytuacji uchylenia tej ostatniej jako praktyki społecznej ojcostwo traci zdolność poręczania czegokolwiek poza użyciem zwykłej siły: metaforze ojcostwa odjęte zostaje jej tradycyjne znaczenie, umożliwiające wgląd w kompleksowe sposoby kodowania władzy politycznej, która podlega kontekstualizacji zarówno w obrębie kodeksu rodzinnego, jak i w ramach kodeksu wspólnoty. Na scenie pozostaje ojciec, który nie potrafił panować ani nad sobą, ani nad rodziną czy wspólnotą, gdyż całkowicie błędnie rozumiał swoje zadania i swój los. Zmiana tej sytuacji, polegająca na zaproponowaniu nowych koncepcji ojcostwa i nowej polityki ich manifestowania, jest tylko kwestią czasu, zaufania oraz siły wyobraźni. Zanim to nastąpi, czytelnicy powieści trwają w zawieszeniu przed niedokończoną sceną porażki. Może rodzinne dziedzictwo postjugosłowiańskich i jugosłowiańskich konfliktów historycznych należałoby w końcu przedstawić z perspektywy kogoś, kto nie ma rodziny lub jej nigdy nie miał?

Powieść Albahariego Danas je sreda stanowi egzemplifikację sytuacji niemożności uznania i zrozumienia świadectwa, a więc jego inkorporacji w doświadczenie osobiste, a przez to - społeczne. Każda próba ukonstytuowania figury ofiary zostaje w powieści zdemaskowana bez względu na to, czy chodzi o ojca, czy o syna. $\mathrm{W}$ parodiująco-fantastycznym kluczu odroczonego zakończenia żaden $\mathrm{z}$ nich nie jest i nie może być pokrzywdzonym. Niemożliwe stają się więc wszelkie próby poświadczania własnych czynów oraz przyjęcia za nie odpowiedzialności, co w dużej mierze łączy narratora powieści i jego ojca. Podwójność tej narracyjnej gry przypomina pobyt $w$ gabinecie krzywych luster: dyskurs odpowiedzialności i zadanie jego społecznego konstruowania, które syn-narrator stawia przed sobą i swoim ojcem jako osobisty imperatyw moralny, okazuje się niemożliwe. Demistyfikacja figury ofiary w powieści Danas je sreda prowadzi do subwersji dyskursu odpowiedzialności, generując pytanie o możliwość znalezienia przyczyny narodzin oraz odnawiania się zła w epoce, w której polityczna poprawność oraz polityki tożsamości ulegają konserwatywnej metastazie, czyli porażce. Wydaje się, że syn-narrator w zatrzymanej scenie niedokończonej partii szachów, którą miał zagrać ze swoim ojcem, nie znalazł sposobu, aby we właściwy sposób postawić to zasadnicze pytanie. Nadeszła więc pora, aby to czytelnik wykonał następny ruch, formułując je i dobitnie artykułując. 
Czekamy zatem na odroczony szach-mat. A może jednak na niekatarktyczny i dlatego właśnie zawsze bolesny remis?

\author{
Ttum. Sylwia Nowak-Bajcar
}

\title{
BIBLIOGRAFIA
}

Albahari, David. Danas je sreda. Beograd: Čarobna knjiga, 2017.

Brooks, Peter. „Freud's Master-plot”. Reading for the Plot: Design and Intention in Narrative. New York: Knopf, 1984. S. 90-112.

Đoković, Nikola. „Brat Davida Albaharija - ispovest o (brato)ubistvu“. Sarajevske sveske 39-40 (2012).

S. 134-154.

Freud, Sigmund. Objaśnianie marzeń sennych. Przeł. Robert Reszke. Warszawa: Wydawnictwo KR, 1996.

Freud, Sigmund. Totem i tabu. Przeł. Jerzy Prokopiuk, Marcin Poręba. Oprac. R. Reszke. Warszawa: Wydawnictwo KR, 1993.

Laub, Dori. „An Event Without a Witness: Truth, Testimony and Survival“. Testimony, Crises of Witnessing in Literature, Psychoanalysis and History. Ed. S. Felman, D. Laub. New York and London: Routledge, 1992.

Miller, David Lee. Dreams of the Burning Child: Sacrificial Sons and the Father's Wittnes. Cornell University Press, 2003.

Pančić, Teofil. „Zločin, kazna i lutrija postojanja“. Vreme (1386) 2017. Web. 15.11.2018. <https://www. vreme.com/cms/view.php?id=1518702>

Prodanović, Mileta. Ultramarin. Beograd: Stubovi kulture, 2010.

Rosić, Tatjana. (Anti)utopije tela: predstavljanje maskuliniteta u savremenoj srpskoj prozi. Beograd: Institut za književnost i umetnost, 2014.

Weineck, Silke-Maria. The Tragedy of Fatherhood. New York, London, New Delhi, Sydney: Bloomsbury, 2014. 